\title{
Molecular Modeling Based Delivery System Enhances Everolimus-Induced Apoptosis in Caco-2 Cells
}

Marwan Abdelmahmoud Abdelkarim Maki ${ }^{l}$, Palanirajan Vijayaraj Kumar ${ }^{1 *}$, Shiau Chuen Cheah ${ }^{2}$, Yeong Siew Wei ${ }^{1}$, Mayasah Al-Nemal ${ }^{1}$, Omer Bayazeid ${ }^{3}$, and Abu Bakar Bin Abdul Majeed ${ }^{4}$

${ }^{1}$ UCSI University, Faculty of Pharmaceutical Sciences, No. 1, Jalan Menara Gading, Taman Connaught, Cheras 56000, Kuala Lumpur, Malaysia

${ }^{2}$ UCSI University, Faculty of Medicine \& Health Sciences, No. 1, Jalan Menara Gading, Taman Connaught, Cheras 56000, Kuala Lumpur, Malaysia

${ }^{3}$ Hacettepe University, Faculty of Pharmacy, Department of Pharmacognosy, 06100, Ankara, Turkey

${ }^{4}$ Universiti Teknologi MARA, Faculty of Pharmacy, Research Management Institute, Shah Alam, Malaysia

*Corresponding Author: Palanirajan Vijayaraj Kumar

Faculty of Pharmaceutical Sciences, UCSI University

No. 1, Jalan Menara Gading, Taman Connaught, Cheras 56000, Kuala Lumpur, Malaysia

Phone: +60103782399 , Ext. 2249

Fax: (+603) 91022614

E-mail: vijayarajkumar_p@yahoo.com 
1. Assessment of FGF7:ß-CD:EV complex stability and EV release profile in Dulbecco's Modified Eagle Medium (DMEM)

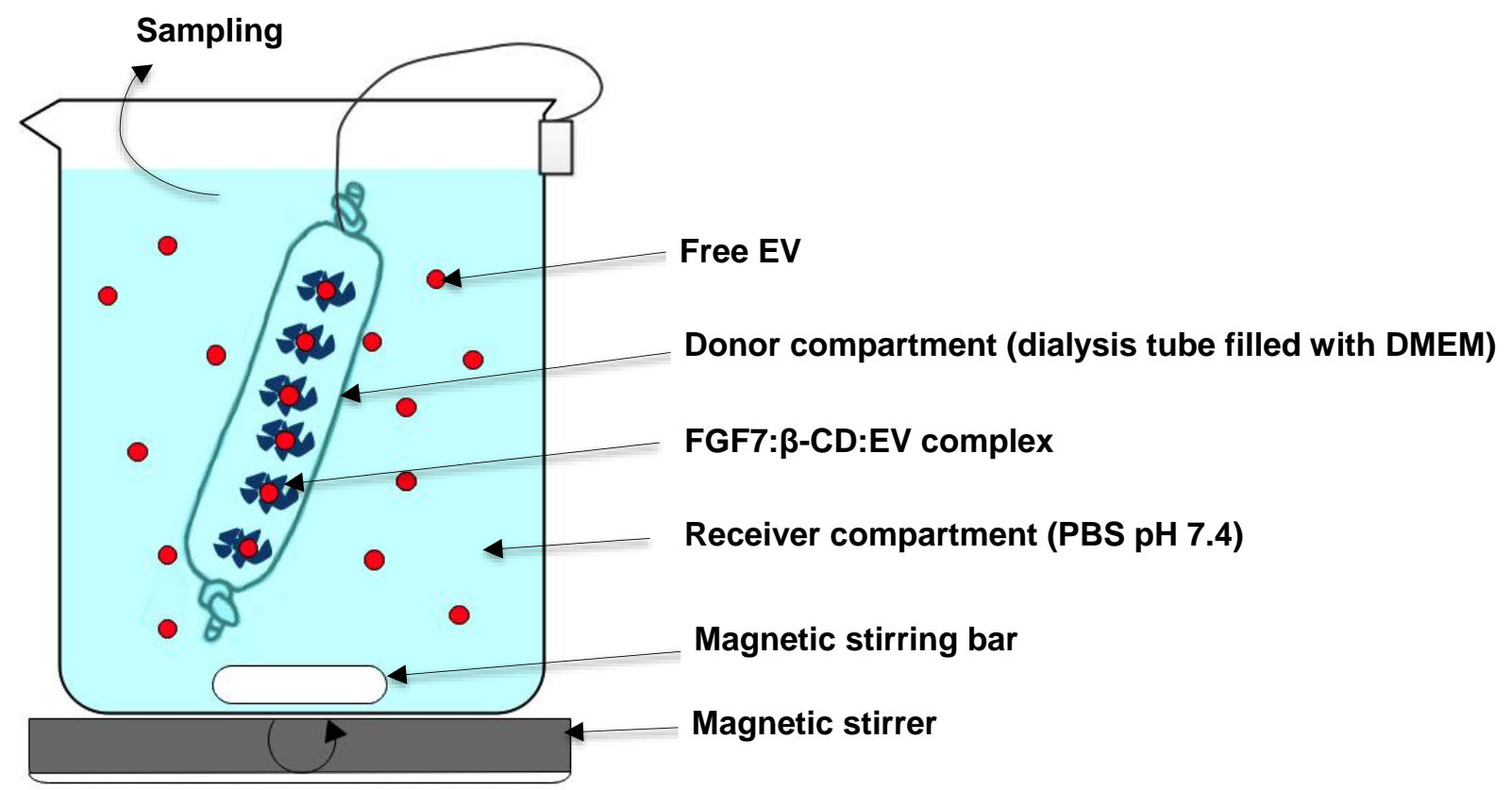

Figure S1. Dialysis tubing procedure 


\section{Cytotoxicity of FGF7:ß-CD:EV complex on normal cells}

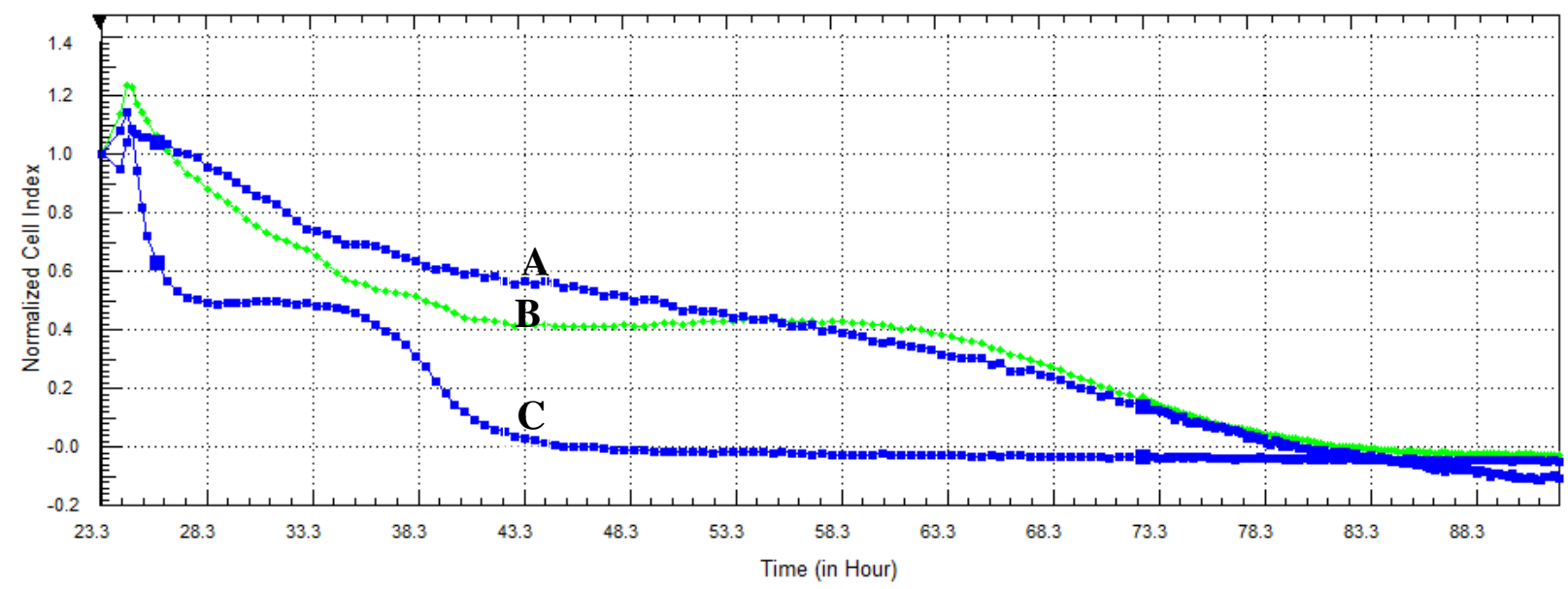

Figure S2. Cytotoxic effect of EV on FHs 74 Int cells as displayed by the RTCA DP instrument. Cells were seeded overnight to reach the $\log$ phase, then incubated with $3.26 \mu \mathrm{M} \mathrm{EV} \mathrm{(A),} 6.52 \mu \mathrm{M} \mathrm{EV} \mathrm{(B),} \mathrm{or} 13.04 \mu \mathrm{M} \mathrm{EV}$ (C). IC $\mathrm{I}_{50}$ value of EV on FHs 74 Int cells was found to be $19.25 \pm 1.35 \mu \mathrm{M}$.

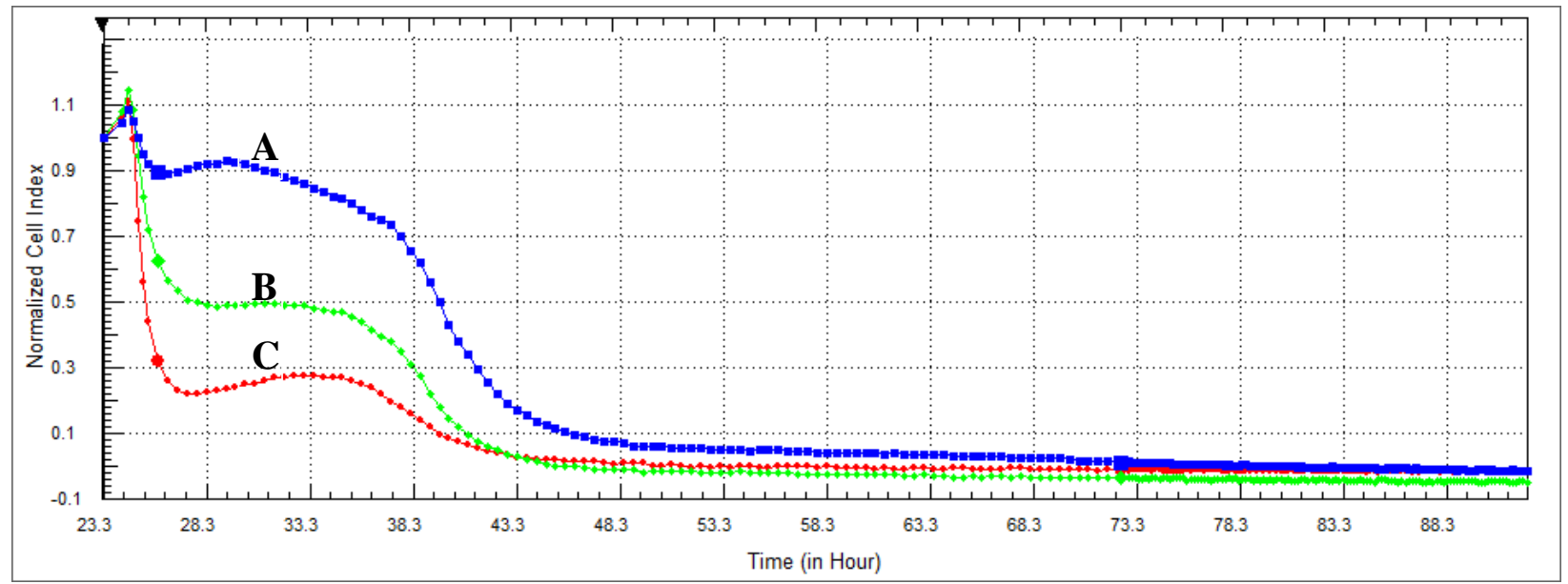

Figure S3. Cytotoxic effect of FGF7:EV on FHs 74 Int cells as displayed by the RTCA DP instrument. Cells were seeded overnight to reach the log phase, then incubated with FGF7:EV complex (contains $1.58 \mu \mathrm{M}$ FGF7 and $3.26 \mu \mathrm{M} \mathrm{EV}$ ) (A), FGF7:EV (contains 1.58 $\mu \mathrm{M}$ FGF7 and $6.52 \mu \mathrm{M}$ EV) (B), or FGF7-EV (contains $1.58 \mu \mathrm{M}$ FGF7 and $13.04 \mu \mathrm{M} \mathrm{EV})(\mathrm{C})$. $\mathrm{IC}_{50}$ value of EV on FHs 74 Int cells was found to be $15.9 \pm 0.95 \mu \mathrm{M}$. 


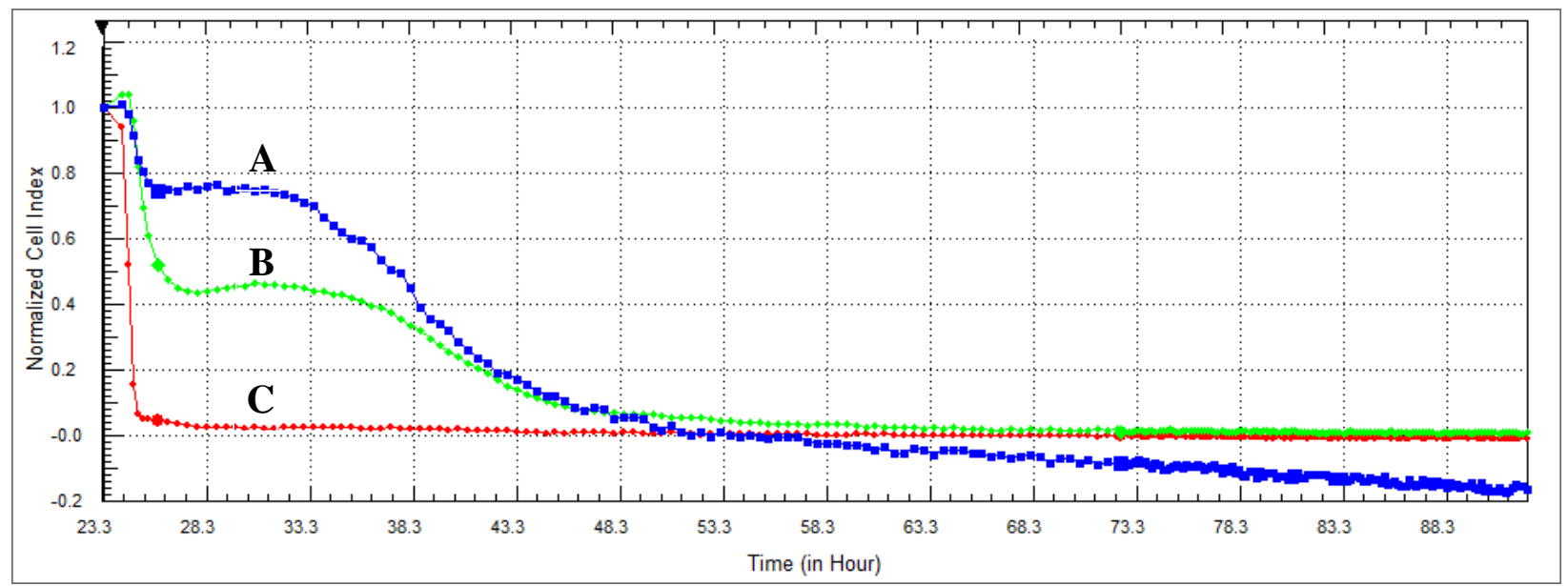

Figure S4. Cytotoxic effect of $\beta-\mathrm{CD}: \mathrm{EV}$ on FHs 74 Int cells as displayed by the RTCA DP instrument. Cells were seeded overnight to reach the log phase, then incubated with $\beta$-CD:EV inclusion complex (contains $3.26 \mu \mathrm{M} \mathrm{EV}$ ) (A), $\beta$-CD:EV inclusion complex (contains $6.52 \mu \mathrm{M} \mathrm{EV}$ ) (B), or $\beta$-CD:EV inclusion complex (contains $13.04 \mu \mathrm{M} \mathrm{EV})(\mathrm{C})$. IC 50 value of EV on FHs 74 Int cells was found to be $16.55 \pm 1.05 \mu \mathrm{M}$.

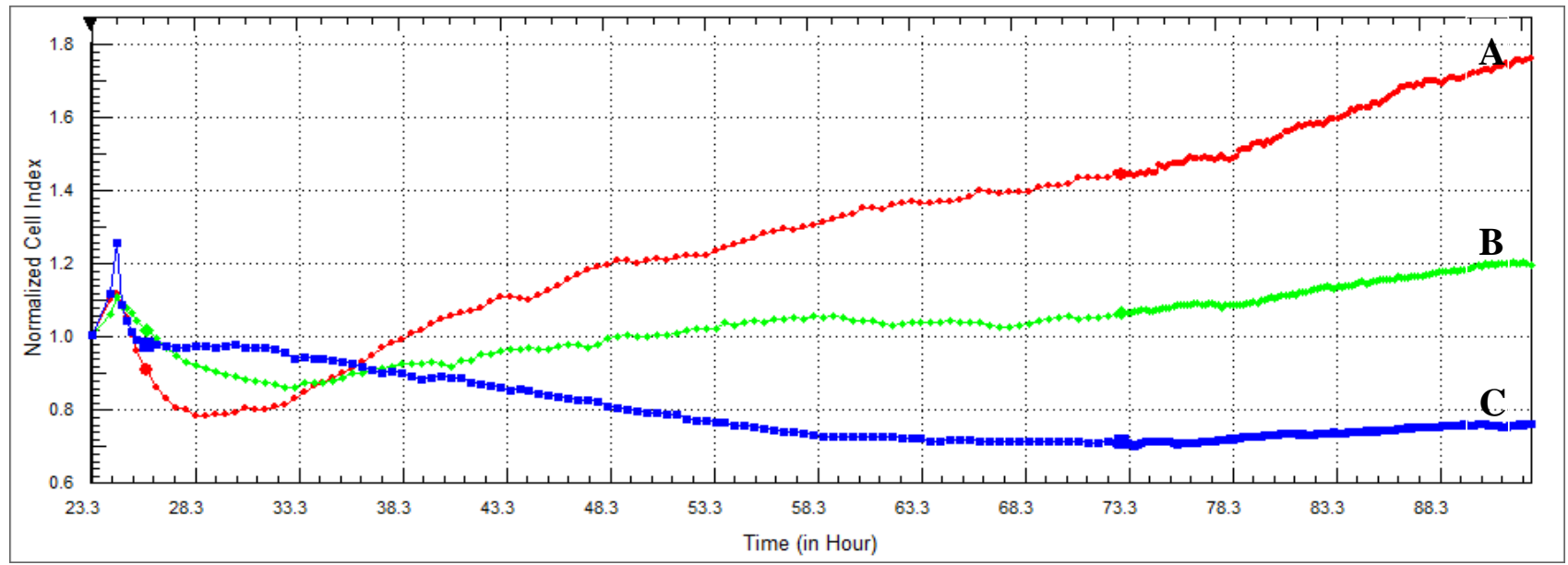

Figure S5. Cytotoxic effect of FGF7: $\beta-C D: E V$ complex on FHs 74 Int cells as displayed by the RTCA DP instrument. Cells were seeded overnight to reach the log phase, then incubated with FGF7: $\beta$-CD:EV complex (contains $1.58 \mu \mathrm{M}$ FGF7, 55.07 $\mu \mathrm{M} \beta-\mathrm{CD}$ and $3.26 \mu \mathrm{M}$ EV) (A), FGF7: $\beta$-CD:EV complex (contains $1.58 \mu \mathrm{M}$ FGF7, $110.13 \mu \mathrm{M} \beta-\mathrm{CD}$ and $6.52 \mu \mathrm{M}$ EV) (B) or FGF7: $\beta$-CD:EV complex (contains $1.58 \mu \mathrm{M}$ FGF7, $220.27 \mu \mathrm{M} \beta-\mathrm{CD}$ and $13.04 \mu \mathrm{M}$ EV) (C). IC 50 value of EV on FHs 74 Int cells was found to be $34.11 \pm 1.9 \mu \mathrm{M}$.

\section{Assessment of FGF7: $\beta-C D: E V$ complex retention in Caco-2 cells}

\section{Chromatographic conditions}

The method is modified from Carpentier et al. ${ }^{1}$ and Spandana et al. ${ }^{2}$. Briefly, treated cells were detached and centrifuged at $400 \mathrm{~g} \mathrm{x} 7$ minutes, then $0.1 \mathrm{ml}$ of tetraborate buffer (pH 9.8), $0.1 \mathrm{ml}$ of EV solution (10 $\mathrm{mg} / \mathrm{L}$ ) as internal standard, and $1.8 \mathrm{ml}$ of dichloromethane/methanol 4:1 (v/v) were immediately added to the cell pellet. After a vigorous agitation, the organic phase was removed and evaporated to dryness. The dry residue was dissolved in the mobile phase: acetonitrile/double ultra-pure water 95:05 (v/v), and injected onto an Ascentis ${ }^{\circledR}$ C18 column (Supelco, Bellefonte PA, USA). The flow rate was $1 \mathrm{ml} / \mathrm{min}$, the peaks were detected by PDA detection and wave length was set at $278 \mathrm{~nm}$. 
The results indicated that the penetration of EV from both samples was time-dependent, thus the accumulation was significantly increased with FGF7: $\beta-C D: E V$ complex application, only 3\% of free EV was detected. The retention of EV was enhanced with the complex application as well. After 24 hours of exposure, $\sim 3.5 \%$ of free drug was detected from cells treated with complex sample, and $\sim 7 \%$ from cells treated with EV only sample.

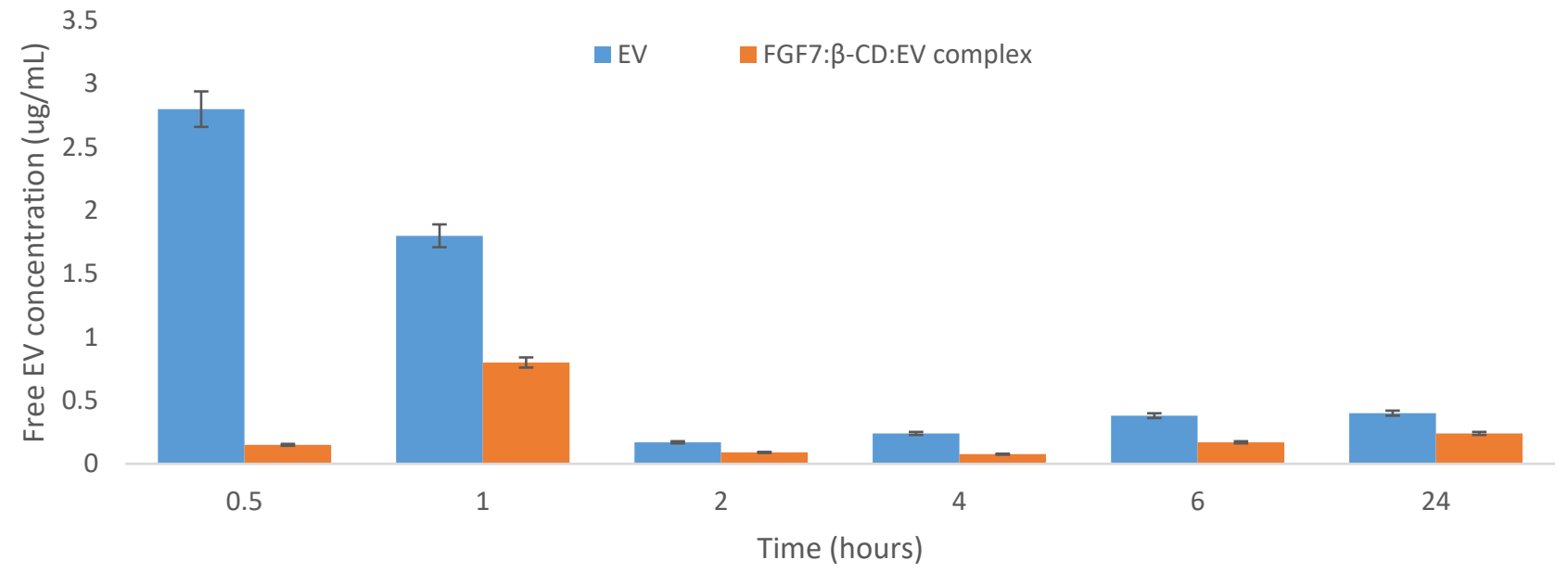

Figure S6. The influence of FGF7: $\beta$-CD complex on the time-dependent rate of Caco- 2 cells uptake and retention of EV for an administered dose of $6.52 \mu \mathrm{M}$. The free EV concentration was measured by HPLC.

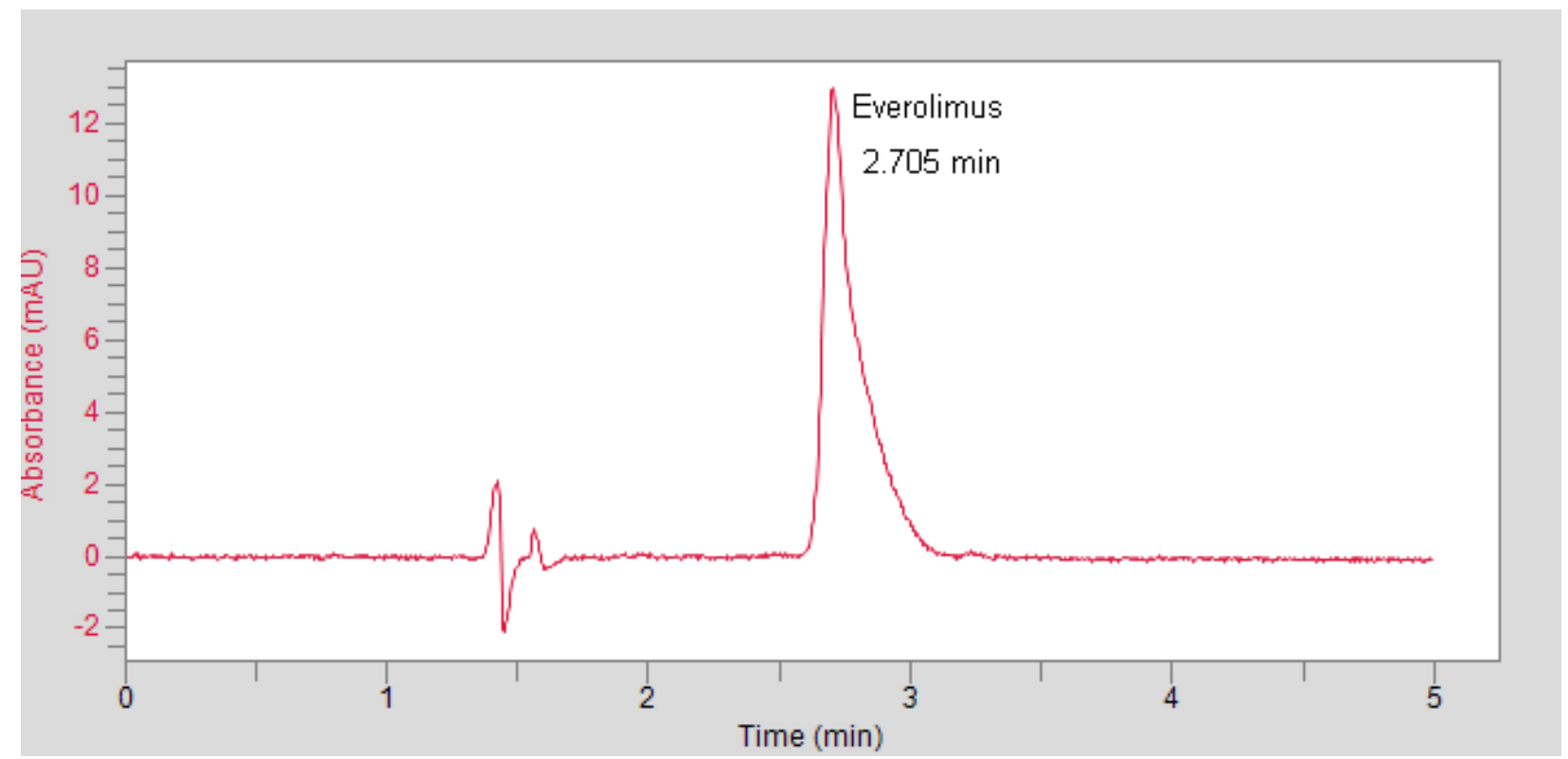

Figure S7. Standard chromatogram of EV $(6.25 \mu \mathrm{g} / \mathrm{mL})$. 


\section{Target Identification of $\beta-C D$ and EV}

Swiss target prediction software has been used for predicting molecular targets of $\beta$-CD and EV ${ }^{3}$. SMILES of $\beta$-CD and EV were obtained from PubChem (Table S1). The consensus molecular targets predicted by Swiss for $\beta-\mathrm{CD}$ and EV are listed in Table S3 and S4.

Table S1. Canonical SMILES of $\beta-C D$ and EV

\begin{tabular}{l|l} 
Name & SMILE \\
\hline $\begin{array}{l}\text { CD } \\
\text { (PUBCHEM CID: 444041) }\end{array}$ & $\begin{array}{l}\mathrm{C}(\mathrm{C} 1 \mathrm{C} 2 \mathrm{C}(\mathrm{C}(\mathrm{C}(\mathrm{O} 1) \mathrm{OC} 3 \mathrm{C}(\mathrm{OC}(\mathrm{C}(\mathrm{C} 3 \mathrm{O}) \mathrm{O}) \mathrm{OC} 4 \mathrm{C}(\mathrm{OC}(\mathrm{C}(\mathrm{C} 4 \mathrm{O}) \mathrm{O}) \mathrm{OC} 5 \mathrm{C}(\mathrm{OC}(\mathrm{C}(\mathrm{C} 5 \mathrm{O}) \mathrm{O}) \mathrm{OC} 6 \\
\mathrm{O}) \mathrm{O}) \mathrm{O}\end{array}$ \\
$\begin{array}{ll}\text { EV } \\
\text { (PUBCHEM CID: 6442177) }\end{array}$ & $\begin{array}{l}\mathrm{CC} 1 \mathrm{CCC} 2 \mathrm{CC}(\mathrm{C}(=\mathrm{CC}=\mathrm{CC}=\mathrm{CC}(\mathrm{CC}(\mathrm{C}(=\mathrm{O}) \mathrm{C}(\mathrm{C}(\mathrm{C}(=\mathrm{CC}(\mathrm{C}(=\mathrm{O}) \mathrm{CC}(\mathrm{OC}(=\mathrm{O}) \mathrm{C} 3 \mathrm{CCCCN} 3 \mathrm{C}(= \\
\mathrm{O}(\mathrm{O} 2) \mathrm{O}) \mathrm{C}(\mathrm{C}) \mathrm{CC} 4 \mathrm{CCC}(\mathrm{C}(\mathrm{C} 4) \mathrm{OC}) \mathrm{OCCO}) \mathrm{C}) \mathrm{C}) \mathrm{O}) \mathrm{OC}) \mathrm{C}) \mathrm{C}) \mathrm{C}) \mathrm{OC}\end{array}$ \\
\end{tabular}

Swiss predicts the molecular targets of small molecules based on their 2D and 3D similarity by comparing the query molecule to a library of 280 thousand compounds. Table S2 and S3 listed the molecular targets of $\beta$-CD and EV respectively. With high probability Swiss predicted that $\beta$-CD could target FGF-7 and FGF-10 (also known as KGF1 and KGF-2, respectively) based on its 3D similarity to CHEMBL198643 (Figure S6) with a similarity score of 0.758 out of $1 \mathrm{EV}$ targets Serine/threonine-protein kinase mTOR.
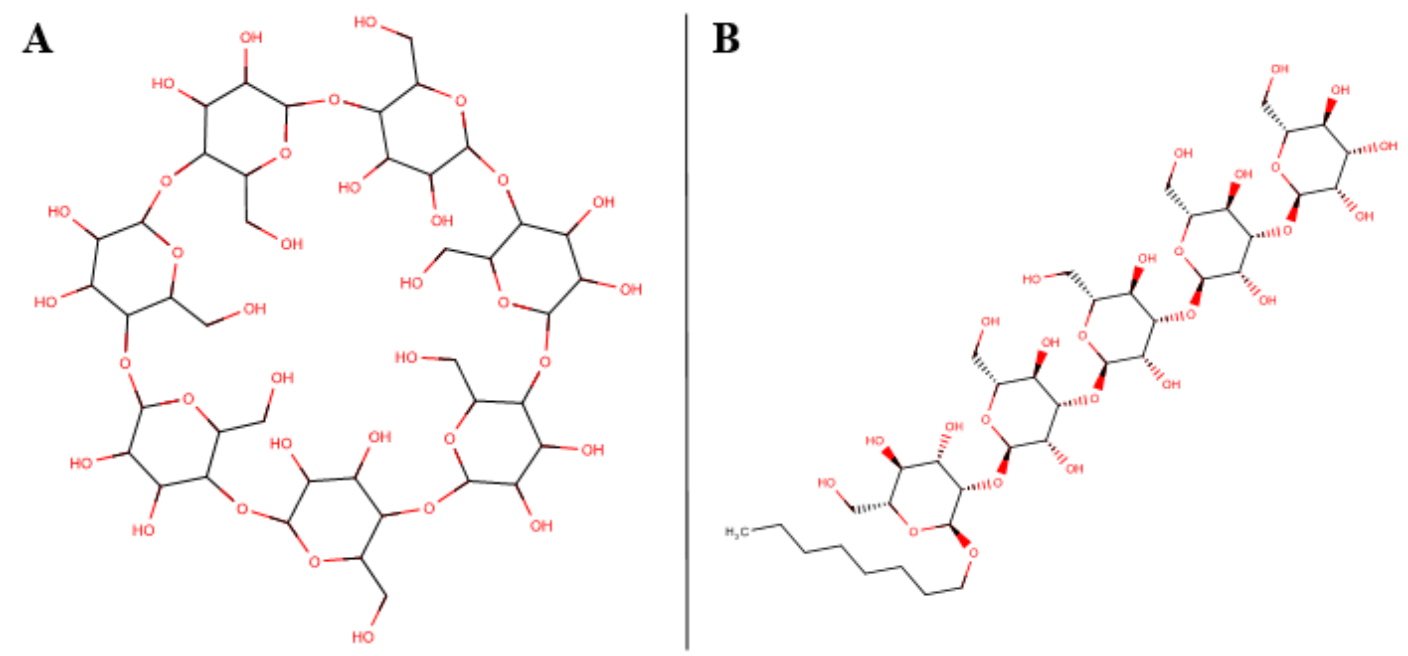

Figure S8. 2D structure of A) $\beta$-CD, B) CHEMBL198643

It has been reported that CHEMBL198643 strongly binds with FGF-1 and $2^{4}$. Based on the shape-similarity theory which states that molecules possessing similar 3D structure might exhibit analogous biological activity, we thought that $\beta$-CD would be able to binds to fibroblast growth factors. This is could be supported by the strong affinity of a similar structure $\left(\beta-C D\right.$ Tetradecasulfate) toward FGF ${ }^{5}$. Heparin is essential for FGF to generate a biological response through binding to FGF receptor. Heparin functions by binding to several FGF molecules forming FGF oligomerization. Then the FGF-heparin complex bind to couple of FGFRs, this leads to FGFR dimerization which 
activates tyrosine kinase pathway. A study showed that synthetic heparin analog which can only bind to one FGF blocks the dimerization of FGFR, thus stopping its activation. We propose that $\beta$-CD antagonizes the action of heparin by binding to only one FGF, therefore it cannot induce FGF oligomerization thus preventing FGFR dimerization and activation ${ }^{6,7}$.

\section{Binding ability of $\beta-C D$ and EV to FGF7}

Molecular docking was performed via the molecular operating environment (MOE.2014) software for $\beta$ $\mathrm{CD}$ and $\mathrm{EV}$ in the heparin binding site of basic fibroblast growth factor (1BFB.pdb) ${ }^{8}$ with scoring affinity London $\mathrm{dG}$ and GBVI/WSA dG. The obtained docking affinity scores are shown in Figure S9.

\begin{tabular}{|c|c|c|c|c|c|c|c|c|c|c|}
\hline & $\mathrm{mol}$ & rseq & mseq & S & rmsd_refine & E_conf & E_place & E_score1 & E_refine & E_score2 \\
\hline 1 & 6442177 & 1 & 1 & -5.0092 & 5.3896 & 249.3156 & -27.0249 & -8.0561 & -17.0150 & -5.0092 \\
\hline 2 & 6442177 & 1 & 1 & -4.8737 & 3.2159 & 238.9634 & -41.8554 & -8.3144 & -14.0658 & -4.8737 \\
\hline 3 & 6442177 & 1 & 1 & -4.8022 & 1.6303 & 256.8998 & -21.7023 & -8.5919 & -15.1917 & -4.8022 \\
\hline 4 & 6442177 & 1 & 1 & -4.7126 & 2.8163 & 245.0996 & -23.7716 & -8.0905 & -13.0527 & -4.7126 \\
\hline 5 & 6442177 & 1 & 1 & -4.7104 & 2.2270 & 238.7883 & -38.0680 & -9.0713 & -12.1594 & -4.7104 \\
\hline 6 & 6442177 & 1 & 1 & -4.6170 & 2.7003 & 254.6145 & -3.1844 & -7.9129 & -17.1669 & -4.6170 \\
\hline 7 & 6442177 & 1 & 1 & -4.4615 & 1.7729 & 238.0406 & -30.6175 & -9.5801 & -14.7607 & -4.4615 \\
\hline 8 & 6442177 & 1 & 1 & -4.2688 & 2.2017 & 237.3359 & -54.2724 & -8.1642 & -11.7695 & -4.2688 \\
\hline 9 & 6442177 & 1 & 1 & -4.0870 & 4.2871 & 247.2750 & -40.7168 & -8.3377 & -8.9479 & -4.0870 \\
\hline 10 & 6442177 & 1 & 1 & -4.0772 & 2.0780 & 256.3575 & 7.1687 & -8.6806 & -7.7938 & -4.0772 \\
\hline 11 & 444041 & 1 & 2 & -5.2439 & 1.9786 & 624.7195 & -64.3874 & -9.1450 & -18.8291 & -5.2439 \\
\hline 12 & 444041 & 1 & 2 & -4.8375 & 2.8882 & 621.0886 & -7.2920 & -9.5388 & -15.1178 & -4.8375 \\
\hline 13 & 444041 & 1 & 2 & -4.5602 & 2.9452 & 615.8110 & -78.4285 & -9.1247 & -11.2252 & -4.5602 \\
\hline 14 & 444041 & 1 & 2 & -4.1812 & 2.3501 & 631.4261 & -66.3765 & -9.6591 & -9.7925 & -4.1812 \\
\hline 15 & 444041 & 1 & 2 & -4.0467 & 4.3664 & 631.7632 & -51.2175 & -9.3040 & -10.8069 & -4.0467 \\
\hline 16 & 444041 & 1 & 2 & -4.0261 & 3.1508 & 625.8408 & -50.4002 & -10.1711 & -11.2005 & -4.0261 \\
\hline 17 & 444041 & 1 & 2 & -3.6537 & 1.6517 & 623.4816 & -80.9887 & -9.6476 & -9.3564 & -3.6537 \\
\hline 18 & 444041 & 1 & 2 & -3.6457 & 2.4040 & 617.8505 & -61.2162 & -9.5400 & -8.0208 & -3.6457 \\
\hline 19 & 444041 & 1 & 2 & -3.6078 & 3.0788 & 624.0917 & -39.1023 & -9.8357 & -9.6159 & -3.6078 \\
\hline 20 & 444041 & 1 & 2 & -3.5234 & 2.3457 & 624.4732 & -56.9427 & -9.2841 & -10.6297 & -3.5234 \\
\hline
\end{tabular}

Figure S9. Docking scores for binding ability of $\beta$-CD (PubChem CID: 444041) and EV (PubChem CID: 6442177) to FGF7, obtained by MOE.2014 software. 


\section{REFERENCES}

1. Carpentier, Y.; Gorisse, M.; Desoize, B., Evaluation of a method for detection of cells with reduced drug retention in solid tumours. Cytometry: The Journal of the International Society for Analytical Cytology 1992, 13 (6), 630-637.

2. Kari, S.; Srinivas, P.; Kumar, A., Rapid and Sensitive HPLC Method for Quantification of Everolimus and Its Application in Release Kinetics of Everolimus Eluting Coronary Stents. Current research in Biological and Pharmaceutical Sciences (CRBPS) 2013, 2 (5).

3. Gfeller, D.; Michielin, O.; Zoete, V., Shaping the interaction landscape of bioactive molecules. Bioinformatics 2013, 29 (23), 3073-3079.

4. Karoli, T.; Liu, L.; Fairweather, J. K.; Hammond, E.; Li, C. P.; Cochran, S.; Bergefall, K.; Trybala, E.; Addison, R. S.; Ferro, V., Synthesis, biological activity, and preliminary pharmacokinetic evaluation of analogues of a phosphosulfomannan angiogenesis inhibitor (PI-88). Journal of medicinal chemistry 2005, 48 (26), 8229-8236.

5. Shing, Y.; Folkman, J.; Weisz, P. B.; Joullie, M. M.; Ewing, W. R., Affinity of fibroblast growth factors for $\beta$-cyclodextrin tetradecasulfate. Analytical biochemistry 1990, 185 (1), 108-111. 6. $\quad$ Hsu, Y.-R.; Nybo, R.; Sullivan, J. K.; Costigan, V.; Spahr, C. S.; Wong, C.; Jones, M.; Pentzer, A. G.; Crouse, J. A.; Pacifici, R. E., Heparin is essential for a single keratinocyte growth factor molecule to bind and form a complex with two molecules of the extracellular domain of its receptor. Biochemistry 1999, 38 (8), 2523-2534.

7. Spivak-Kroizman, T.; Lemmon, M.; Dikic, I.; Ladbury, J.; Pinchasi, D.; Huang, J.; Jaye, M.; Crumley, G.; Schlessinger, J.; Lax, I., Heparin-induced oligomerization of FGF molecules is responsible for FGF receptor dimerization, activation, and cell proliferation. Cell 1994, 79 (6), 10151024.

8. Faham, S.; Hileman, R. E.; Fromm, J. R.; Linhardt, R. J.; Rees, D. C., Heparin structure and interactions with basic fibroblast growth factor. Science (New York, N.Y.) 1996, 271 (5252), 1116-20. 